\title{
In vitro Development of Resistance to Azithromycin in Pseudomonas aeruginosa
}

\author{
Thanmin Jarana Thammi ${ }^{1}$, Md. Masud Rana ${ }^{2}$, Farhanur Rahman ${ }^{1}$, \\ Apu Banik ${ }^{1}$ and Md. Anwar UI Islam²
}

${ }^{1}$ Department of Pharmacy, Noakhali Science and Technology University, Noakhali-3814, Bangladesh

${ }^{2}$ Department of Pharmacy, University of Rajshahi, Rajshahi-6205, Bangladesh

Received: October 08, 2017; Accepted: December 13, 2017; Published: January 30, 2018)

\begin{abstract}
Antimicrobial resistance has been considered as a growing public health problem all over the world. Due to improper use of antibiotics many bacterial species including the Pseudomonas aeruginosa become resistant. So, the objectives of this study were to determine the success or failure of antibiotic therapy. Tests were performed in vitro and measured the growth response of an isolated bacterium to a particular drug. This study determined the zone of inhibition, minimum inhibitory concentration (MIC) and time at which bacteria showed resistance. From sensitivity test, it showed that $P$. aeruginosa is sensitive to azithromycin antibiotic. MIC level of $P$. aeruginosa that was found from the analysis was $3 \mu \mathrm{g} / \mathrm{ml}$ and from further analysis it was found that $P$. aeruginosa grew resistance when it got up to $2.5 \mu \mathrm{g} / \mathrm{ml}$ concentration of antibiotic below MIC level for 24 hours. When the $P$. aeruginosa was treated with the concentration upto $2.5 \mu \mathrm{g} / \mathrm{ml}$ for 24 hours then it showed growth at the concentration of MIC level. It means that $P$. aeruginosa got the drug below MIC level for a certain period and became resistant to azithromycin.
\end{abstract}

Key words: In vitro, Azithromycin, Resistance, Pseudomonas aeruginosa.

\section{Introduction}

The antimicrobial resistance is increasing worldwide at an alarming rate. According to world health organization (WHO), antimicrobial resistance is one of the greatest threats to human health. In 2001, at least one of the currently available antibiotics became resistant due to pathogenic bacteria (Cragg and Newman 2001). In recent years, indiscriminate uses of antibiotics lead to antibiotic resistance (Haque et al. 2014). The prevalence of drug resistant lead to high mortality rates in immune compromised persons (Valan et al, 2009).

Most of the people in Bangladesh specially who are living in lowers socio-economic condition and lacking minimum health related facilities are often seen to take antibiotic at an irregular course. That's why microorganisms get the concentration or amount of drug which are enough to make them resistant to that drug. This bad habit are generating some unavoidable problems. This trend is directing our public health to a danger point . This is seen to impart a negative effect on the pharma antibiotic market and also increasing medical treatment cost.

$P$. aeruginosa is an aerobic bacterium with unipolar motility (Ryan and Ray 2004). $P$. aeruginosa can secrete a variety of pigments, including pyocyanin, pyoverdine, and pyorubin (King et al. 1954). Some Pseudomonal species were considered the causative agents of old diseases now are being reexamined for their potential use as biological warfare agents.

So, on the basis of the socio-economic condition of our country and health status of peripheral countryman it is urgently needed to carry out more and more fruitful studies about the antibiotic resistance and direct the unconscious people to a

Correspondence to: Md. Anwar Ul Islam; E-mail: profanwarulislam@yahoo.com 
position where they will be more conscious about the importance of taking the full course antibiotic.

\section{Materials and Methods}

Collection and Pure Culture of Isolates: In this study total ten samples were collected from the drains of General Hospital, Prime Hospital, Royal Hospital and the wastewater channel of Globe pharmaceuticals in Noakhali. Bacterial strains were isolated from the samples and minimal inhibitory concentrations were determined. The collected samples were directly plated on nutrient agar plate through cotton bud and incubated at $37^{\circ} \mathrm{C}$ for $24-48$ hours. After the incubation period the plates were observed for any kind of growth on the media. The numbers of smooth colonies were counted. Then the colonies were randomly selected and streaked on the nutrient agar plate for purification. Pure culture of twenty different isolates was formed and the collected isolates were stored at $-50^{\circ} \mathrm{C}$. Among twenty isolates, Isolate 2 was considered as $P$. aeruginosa using biochemical test.

Identification of bacterium using different agar media: For identification of $P$. aeruginosa, MacConkey agar, Eosine methylene Blue (EMB) agar, Cetrimide agar, Mannitol salt agar (MSA) and cystine lactose electrolyte deficient medium (CLED) were used.

Biochemical test: Some biochemical tests were also carried out for the characterization of $P$. aeruginosa such as Oxidase test, Urease test, Indole test, Citrate test and Triple Sugar Iron (TSI) test. Morphological characters of selected isolate were observed by cultural and microscopic methods. By the cultural method using selective media such as CLED agar media, Cetrimide agar, blood agar, macconkey agar media colony characteristics were observed. Microscopic methods were used for the study of size, shape, arrangement, color etc. Biochemical tests were used which were more important than morphological characteristics in the identification of bacteria up to species using "Bergey's Manual of bacteriology", $9^{\text {th }}$ edition.

Antibacterial assay against $P$. aeruginosa: Antibacterial activity of antibiotics was evaluated in vitro against $P$. aeruginosa by disc diffusion assay (Bauer et al. 1966). P. aeruginosa bacterium was streaked on two petri-plates. The plates were occupied by ten antibiotic disks and kept for incubation for 24 hours. Then the zone of inhibition was measured using a millimeter scale.

Minimum Inhibitory Concentration (MIC) tests: MIC test of azithromycin was done by serial tube dilution technique or turbidimetric assay against $P$. aeruginosa (Reiner, 1982). 15 test tubes were taken and each of the test tubes was filled with $9 \mathrm{ml}$ McFarland solution. Then the antibiotic solutions were added. Different concentrations such as1, 2, 3, $4,5,6,7,8,9,10,11,12,13,14$ and $15 \mu \mathrm{g} / \mathrm{ml}$ were prepared and incubated at $24 \mathrm{hrs}$. Finally, the growth of bacteria was observed to find out the minimum concentration at which bacteria could not grow.

Resistance development test: As the MIC level for $P$. aeruginosa against azithromycin antibiotic was $3 \mu \mathrm{g} / \mathrm{ml}$ so antibiotic solution of 1.0, 1.5, 2.0, 2.5, 3.0 $\mu \mathrm{g} / \mathrm{ml}$ concentration were prepared These solution of azithromycin was added to the test tube containing 9 $\mathrm{ml}$ nutrient broth solution. Sample containing bacteria and drug $(1.0,1.5,2.0$ and $2.5 \mu \mathrm{g} / \mathrm{ml})$ were observed after 24 hours to see the growth of $P$. aeruginosa. If growth was observed, then the bacteria was treated with drug at MIC level and observed after $24 \mathrm{hrs}$. If growth was found at MIC level then it could due to resistance developed in microorganisms.

\section{Results and Discussion}

$P$. aeruginosa is a gram-negative rod-shaped bacterium that can cause disease in plants, animals and humans. It is an opportunistic pathogen, often causing nosocomial infections. In addition to causing serious and life threatening diseases, this organism exhibits innate resistance to many antibiotics and can develop new resistance after exposure to antimicrobial substances.

In biochemical analysis, the selected bacterial strain showed negative in gram staining, indole test and urease test whereas positive result found in citrate and oxidase test (Table 1). 
Isolate 2 contains large genome (5.5-7.5 Mb) and encodes between 5,500 and 6,500 open reading frames (Klockgether et al. 2011). It was analyzed that 5,021 genes are present across the first five genomes with at least $70 \%$ sequence identity .This set of genes is considered as $P$. aeruginosa core genome (Mathee et al. 2008).

Isolate 2 showed saffranin or red color which indicates that the strain is gram-negative. Morphological, cultural and biochemical analysis were done and it was confirmed that the Isolate 2 is $P$. aeruginosa. Disc diffusion method was used to measure bacterial susceptibility (Bauer et al, 1966). Ampicillin $(10 \mu \mathrm{g})$, Cloxacillin $(1 \mu \mathrm{g})$, Amoxacillin $(20 \mu \mathrm{g})$, Ceftriaxone $(30 \mu \mathrm{g})$, Clindamycin $(30 \mu \mathrm{g})$, Ciprofloxacin $(30 \mu \mathrm{g})$, Azithromycin $(5 \mu \mathrm{g})$, Gentamicin $(15 \mu \mathrm{g})$, Cotrimoxazole $(10 \mu \mathrm{g})$ and Chloramphenicol $(25 \mu \mathrm{g})$ antimicrobial disks were used.

Table 1. Identification of $P$. aeruginosa.

\begin{tabular}{ll}
\hline Test Performed & Isolate 2 \\
\hline MacConkey agar media & White or colorless colony \\
Eosine methylene blue agar media & Pinkish mucoid colonis \\
Cystine lactose electrolyte deficient medium & Green Colonies \\
Mannitol salt agar media & No Growth \\
Cetrimide agar media & Yellow green to blue colonies \\
Tripple Super Iron test & Red slant and red butt \\
Indole Test & Negative \\
Citrate Test & Positive \\
Oxidase test & Positive \\
Urease Test & Negative \\
Gram staining & Negative \\
\hline
\end{tabular}

Table 2. Zone of inhibition of different antibiotics against $P$. aeruginosa.

\begin{tabular}{llcc}
\hline Name of bacterium & Tested Antibiotic & Disk potency & Zone of inhibition $(\mathrm{mm})$ \\
\hline & Ampicillin & $10 \mu \mathrm{g}$ & 12 \\
& Cloxacillin & $1 \mu \mathrm{g}$ & 13 \\
& Amoxacillin & $20 \mu \mathrm{g}$ & 15 \\
Pseudomonas & Ceftriaxone & $30 \mu \mathrm{g}$ & 16 \\
aeruginosa & Clindamycin & $30 \mu \mathrm{g}$ & 16 \\
& Ciprofloxacin & $30 \mu \mathrm{g}$ & 17.5 \\
& Azithromycin & $5 \mu \mathrm{g}$ & 18 \\
& Gentamicin & $15 \mu \mathrm{g}$ & 13.5 \\
& Cotrimoxazole & $10 \mu \mathrm{g}$ & 13 \\
& Chloramphenicol & $25 \mu \mathrm{g}$ & 15 \\
\hline
\end{tabular}

From Table 2 it is seen that azithromycin shows largest zone of inhibition that means it is more sensitive to $P$. aeruginosa bacteria. 
Table 3. Minimum Inhibitory Concentration (MIC) test of azithromycin against P. aeruginosa.

\begin{tabular}{ccc}
\hline $\begin{array}{c}\text { Number of } \\
\text { test tubes }\end{array}$ & Concentration $(\mu \mathrm{g} / \mathrm{ml})$ & Growth of $p$. aeruginosa \\
\hline 1 & 1 & + \\
2 & 2 & + \\
$\mathbf{3}$ & $\mathbf{3}$ & - \\
4 & 4 & - \\
5 & 5 & - \\
6 & 6 & - \\
7 & 7 & - \\
8 & 8 & - \\
9 & 9 & - \\
10 & 10 & - \\
11 & 11 & - \\
12 & 12 & - \\
13 & 13 & - \\
14 & 14 & - \\
15 & 15 & - \\
\hline
\end{tabular}

The sign "+" = growth "-" = no growth. Table 3 showed no growth of $P$. aeruginosa at or above $3 \mu \mathrm{g} / \mathrm{ml}$ of azithromycin. Therefore, $3 \mu \mathrm{g} / \mathrm{ml}$ was the MIC level.

Table 4. Resistance development of $P$. aeruginosa against azithromycin.

\begin{tabular}{ccc}
\hline $\begin{array}{c}\text { Sample containing } \\
\text { bacteria }\end{array}$ & $\begin{array}{c}\text { Addition of azithromycin } \\
\text { solution }\end{array}$ & Bacterial growth \\
\hline $9 \mathrm{ml}$ & $1.0 \mu \mathrm{g} / \mathrm{ml}$ & $\begin{array}{l}\text { Subjected in } \\
\text { incubator for } 24 \mathrm{hrs}\end{array}$ \\
$9 \mathrm{ml}$ & $1.5 \mu \mathrm{g} / \mathrm{ml}$ & + \\
$9 \mathrm{ml}$ & $2.0 \mu \mathrm{g} / \mathrm{ml}$ & + \\
$9 \mathrm{ml}$ & $2.5 \mu \mathrm{g} / \mathrm{ml}$ & + \\
$9 \mathrm{ml}$ & $\begin{array}{c}\text { Treated the bacteria with the } \\
\text { antibiotic at MIC } \\
(3 \mu \mathrm{g} / \mathrm{ml}) \text { level }\end{array}$ & $\begin{array}{c}\text { Bacterial growth was } \\
\text { observed }\end{array}$ \\
& & \\
\hline
\end{tabular}

From Table 4 it is seen that as $P$. aeruginosa bacteria gets drug up to $2.5 \mu \mathrm{g} / \mathrm{ml}$ for $24 \mathrm{hrs}$ then it shows growth at MIC level that means the bacteria get resistant.

\section{Conclusion}

In $21^{\text {st }}$ century, drug resistance among bacteria is a global health problem. There is no doubt that we are now facing greater antibiotic resistance challenges than ever before, limiting treatment options for patients with severe infections. Now-adays new antimicrobial agents have failed to keep pace with the ingenuity of resistant bacteria. So, we have to adapt this threat by reducing unnecessary antibiotic prescribing, both qualitatively and quantitatively. Therefore, we need to minimize the risk of spreading resistant bacteria, and we have to find novel compounds active against resistant bacteria. 


\section{Declaration of Interests}

The authors have no conflicts of interests.

\section{References}

Bauer, A.W., Kirby, W.M., Sherris, J.C. and Turek, M. 1966. Antibiotic susceptibility testing by a standardized single disk method. American J. Clin. Pathology. 45, 493-496.

Cragg, G.M. and Newman, D.J. 2001. Medicinals for the millennia: The historical record. Ann. N. Y. Acad. Sci. 953, 3-25.

Haque, M.A., Sarker, A.K., Islam, M.S., Rahman, M.A., Chouduri, M.A.U. and Islam, M.A. 2014. In vitro insecticidal and time-kill profile of ethyl acetate extract of marine Streptomyces sp. Isolated from Sundarbans, Bangladesh. Bangladesh Pharm. J. 17, 151- 156.

King, E.O., Ward, M.K. and Raney, D.E. 1954. "Two simple media for the demonstration of pyocyanin and fluorescein". J. Lab. Clin. Med. 44, 301-307.
Klockgether, J., Cramer, N., Wiehlmann, L., Davenport, C.F. and Tümmler, B. 2011. Pseudomonas aeruginosa Genomic Structure and Diversity. Frontiers in Microbiology. 2, 150.

Mathee, K., Narasimhan, G, Valdes., C, Qiu. X., Matewish, J.M., Koehrsen, M., Rokas, A., Yandava, C.N., Engels, R., Zeng, E., Olavarietta, R., Doud, M., Smith, R.S., Montgomery, P., White, J.R., Godfrey, P.A., Kodira, C., Birren, B., Galagan, J.E. and Lory, S. 2008. Dynamics of Pseudomonas aeruginosa genome evolution. Proc. Natl. Acad. Sci. U.S.A. 105, 31003105.

Reiner, R. 1982. Detection of antibiotic activity.In antibiotic introduction. Roche Scientific Service, Switzerland. 1, 21-25.

Ryan, K.J. and Ray, C.G. eds. 2004. Sherris Medical Microbiology (4th ed.). Mc. Graw. Hill.

Valan, A.M., Duraipandiyan, V., Agastian, P. and Ignacimuthu, S. 2009. In vitro antimicrobial activity of Streptomyces spp. ERI-3 isolated from Western Ghats rock soil (India). J. Med. Mycology. 19, 22-28. 